\title{
Production of Plant Growth-Promoting Bacteria Biofertilizer from Organic Waste Material and Evaluation of Its Performance on the Growth of Corn (Zea mays)
}

\author{
Christie Oby Onyia ${ }^{*}$, Amarachi Mariam Okoh¹, Okoh Irene² \\ ${ }^{1}$ Department of Biotechnology, Godfrey Okoye University, Thinkers Corner, Enugu, Nigeria \\ ${ }^{2}$ Department of Microbiology, Godfrey Okoye University, Thinkers Corner, Enugu, Nigeria \\ Email: *onyia01@hotmail.com, c.onyia@gouni.edu.ng
}

How to cite this paper: Onyia, C.O., Okoh, A.M. and Irene, O. (2020) Production of Plant Growth-Promoting Bacteria Biofertilizer from Organic Waste Material and Evaluation of Its Performance on the Growth of Corn (Zea mays). American Journal of Plant Sciences, 11, 189-200.

https://doi.org/10.4236/ajps.2020.112015

Received: December 8, 2019

Accepted: February 18, 2020

Published: February 21, 2020

Copyright $\odot 2020$ by author(s) and Scientific Research Publishing Inc. This work is licensed under the Creative Commons Attribution International License (CC BY 4.0).

http://creativecommons.org/licenses/by/4.0/

cc) (i) Open Access

\begin{abstract}
Biofertilizer can be defined as preparation that contains microbes capable of nitrogen $(\mathrm{N})$-fixation and phosphate solubilization that promote plant growth. These groups of microbes, classified as Plant Growth-Promoting Bacteria (PGPB), colonize the rhizosphere and the soil. In this work, liquid biofertilizer was produced from whole orange, banana and grape, wheat and rice chaff, Moringa oleifera leaves, soil, and brown sugar (as carbon source) mixed with water and cultured in an anaerobic condition for two weeks. The sieved culture was stored in a tightly sealed PVC container at room temperature for biochemical analysis of microbial population. Nitrogen fixing bacteria (Azotobacter $s p$.) and phosphorus solubilizing bacteria were isolated using Ashby's Mannitol Azotobacter medium and Pisvikoya's PSB medium respectively, while Bacillus sp. was isolated using Bacillus agar. Field experiment was carried out to investigate the performance rates of the biofertilizer against those of the Nitrogen/Phosphorus/Potassium (NPK) chemical fertilizer and the control, on the growth of corn (Zea mays). The experimental design consisted of three treatments of the Biofertilizer, Chemical fertilizer (NPK) and Control, conducted in three replicates. Data collected were analyzed using one-way ANOVA at $P<0.05$. The results showed significant improvement in growth and yield of maize on which biofertilizer was applied as against those treated with NPK and the Control. The plants treated with the biofertilizer did not show signs of insects attack, which were easily observed on the blades of those treated with NPK and the control.
\end{abstract}

\section{Keywords}

Biofertilizer, Zea mays, NPK, Bacillus sp., Azotobacter sp., PGPB 


\section{Introduction}

Fertilizers play an important role in agricultural system mainly in increasing yield. Synthetic fertilizers were a part of the technology that contributed to the Green Revolution and millions of tons of chemical fertilizers have continued to be used the world over [1]. However, excessive application of chemical fertilizers has resulted in adverse environmental impacts and ecological challenges [2] [3]. Some of these negative impacts include: water body pollution/eutrophication and algal bloom, land degradation, food and food crop-products contamination, adverse human health effects, greenhouse effect/ozone layer depletion and general imbalance of the ecosystem [4]. These adverse effects have led to the introduction of microbial inoculants/biofertilizers for plant growth and development [5], which include Plant Growth-Promoting Microorganisms such as nitrogen fixing and phosphate solubilizing microorganisms [6]. Nitrogen is a very important factor that may limit plant growth and food production as it is an essential component of chlorophyll-a pigment that alongside amino acids, promote photosynthesis [7]. Nitrogen gas $\left(\mathrm{N}_{2}\right)$, although one of the predominant elements in the atmosphere, can only be utilized by plants in reduced form, of ammonia and nitrate fertilizer or biological nitrogen fixation. Some of the soil nitrogen-fixing-bacteria include species of Azotobacter sp., Bacillus sp., Clostridium, and Klebsiella [7].

Phosphorus is the second most important element required for plant growth, next to Nitrogen [8]. Although large amount of phosphorus fertilizer are applied for soil fertility improvement, most of it $(20 \%-80 \%)$ are immobilized in the soil, making them unavailable for plant use [9]. It was reported that only $0.1 \%$ of the total Phosphorus is available for plant up-take due to Phosphorus fixation by some species of bacteria and fungi in the soil and rhizosphere [10]. [11] reported that bacteria solubilize phosphorus are more effectively than fungi. Strains from bacterial genera-Pseudomonas, Bacillus, Rhizobium and Enterobacter along with Penicillium and Aspergillus fungi are the most powerful Phosphorus solubilizers [12]. Researchers have discovered the development and use of biofertilizers as an environmentally-friendly, cost-effective and efficient fertilizer that can boost crop productivity as well as maintain the purity of the soil [12].

Biofertilizer is any substance which contains living microorganisms that can inhabit the rhizosphere or soil and promotes the growth of plant by promoting the availability of the primary plant nutrient when applied to the soil, surface of plant or seed [14] [15] [16], on the other hand, described biofertilizer as materials that include manure and plant extracts which contain microorganisms that promote plant growth. This group of microorganisms is known as plant growth promoting bacteria (PGPB), some of which promote plant growth by fixing atmospheric nitrogen and solubilizing phosphorus. Also, [17] defined biofertilizer as preparation containing live or latent cells of microorganisms or their metabolites, which when inoculated to seed, soil or roots of seedlings, promote plant 
growth and enhance harvestable yield. This definition separated biofertilizer from organic fertilizer which contains organic matters [17]. This application is based on the use of decomposing organic matters, crops remains, animal sewage and microorganisms, to enhance nutrients in the plant rhizosphere, soil stability, quick decomposition of organic matters and mycorrhiza symbiosis association [18].

The experiment was conducted at Isu-Aniocha, Awka North Local Government Area of Anambra State, Nigeria.

\section{Materials}

Fresh soil sample, from the soil rhizosphere, taken from $5 \mathrm{~cm}$ beneath the soil surface, dry grass, water hyacinth (Eichornia crassipes), leguminous plants (e.g. Leucaena leucocephala), rice chaff, wheat chaff, brown sugar, moringa leaves, orange, banana, grape, cucumber, poultry litter and sewage, microkjeldal flask, weighing balance, beakers, retort stand, burette, flat bottom flask, Bunsen burner, distillation column, conical flask.

\section{Methods}

The methods employed at the different stages of the production and the product testing, include: culturing of microorganisms, isolation of microorganisms, characterization of the experimental soil, biofertilizer and chemical/synthetic fertilizer.

\section{Microorganism Culture}

The microorganism was cultured, using $500 \mathrm{gm}$ of the fresh soil sample from the soil rhizosphere, collected from $5 \mathrm{~cm}$ beneath the soil surface, $500 \mathrm{gm}$ of wheat chaff and rice chaff, mixed with water until a homogenous mixture was obtained. The mixture was transferred into a covered container with a depression in the center to allow air circulation and ventilation. The container was kept under a shade and allowed to stand for seven days.

\section{Production of Liquid Bio Fertilizer}

Nine kilogramme $(9 \mathrm{~kg})$ of mixed fruits-oranges, cucumber, bananas, grape, moringa leaves were cut into tiny pieces and loaded into a container. $1 \mathrm{~kg}$ of brown sugar and $1 \mathrm{~kg}$ of the microorganism culture was added into the container in the ratio of 1:1.

The materials were mixed properly together, until the mixture became consistent. Sterile water was added into the container and stirred in one direction for few minutes. The container was tightly sealed and kept in a dark place for two weeks without any disturbance. The mixture was sieved and the liquid (biofertilizer) was transferred into a gallon and kept in a shady cool dry place ready for further analysis. 


\section{Isolation of Microorganisms}

\section{Nitrogen Fixing Bacteria, Phosphorus Solubilizing Bacteria (PSB)}

The liquid (biofertilizer) produced above, was cultured using two selective media (for Azotobacter and Phosphorus Solubilizing Bacteria (PBS) respectively).

PSB bacteria, Pikovskaya agar medium [19] were prepared with the following quantity and components: glucose-2.5 g, $\mathrm{Ca}_{3}\left(\mathrm{PO}_{4}-1.25 \mathrm{~g}, \mathrm{NaCl}-0.05 \mathrm{~g}\right.$, $\mathrm{MgSO}_{4} \cdot 7 \mathrm{H}_{2} \mathrm{O}-0.000625 \mathrm{~g}, \mathrm{MnSO}_{4} \cdot 2 \mathrm{H}_{2} \mathrm{O}-0.000625 \mathrm{~g}, \mathrm{FeSO}_{4} \cdot 7 \mathrm{H}_{2} \mathrm{O}-0.000625$ $\mathrm{g}$, yeast $-1.25 \mathrm{~g}$ and $5 \mathrm{~g}$ of agar. The medium was diluted in $250 \mathrm{ml}$ of distilled water and sterilized in an autoclave at the temperature of $121^{\circ} \mathrm{C}$ for 15 minutes. The agar was poured into a plate (Petri dish) and was allowed to solidify at room temperature. Serial dilution was made and the sample was swabbed on the solidified agar with a swab stick and incubated at room temperature.

\section{Isolation of Phosphorus Solubilizing Bacteria}

\subsection{Azotobacter spp.}

Mannitol Ashby agar media was prepared with the following composition: $5 \mathrm{~g}$ of Mannitol, $0.05 \mathrm{~g}$ of Potassium Hydrogen Phosphate $\left(\mathrm{K}_{2} \mathrm{HPO}_{4}\right), 0.05 \mathrm{~g}$ of Sodium Chloride $(\mathrm{NaCl}), 0.05 \mathrm{~g}$ of Magnesium Sulphate Heptahydrate $\left(\mathrm{MgSO}_{4} \cdot 7 \mathrm{H}_{2} \mathrm{O}\right)$, $0.025 \mathrm{~g}$ of Potassium Sulphate $\left(\mathrm{K}_{2} \mathrm{SO}_{4}\right), 1.25 \mathrm{~g}$ of Calcium Carbonate $\left(\mathrm{CaCO}_{3}\right)$ and $5 \mathrm{~g}$ of agar. The mixture was diluted in $250 \mathrm{ml}$ of distilled water and sterilized in an autoclave at the temperature of $121^{\circ} \mathrm{C}$ for 15 minutes. The agar was poured into a petri dish and allowed to solidify at room temperature. Serial dilution was made and the sample was swabbed on the solidified agar with a swab stick and incubated at room temperature.

\subsection{Bacillus spp.}

Hicrome Bacillus agar differential medium for identification of Bacillus species was used to isolate Bacillus subtilis, Bacillus megaterium and Bacillus thuringiensis.

\section{Chemical Characterization of the Experimental Soil, Bio- fertilizer and Chemical Fertilizer}

\subsection{Soil Nutrient Analysis}

The soil was characterized for Nitrogen, Potassium and Phosphorus nutrient content before the planting.

\subsection{Nitrogen Content of the Biofertilizer}

The microkjeldal method was used for the determination of Nitrogen. 1 gram of the soil sample weighed into a kjeldahl flask, and 10 gram of sodium sulphate was added into it, followed by $20 \mathrm{ml}$ of concentrated sulphuric acid and 1 gram of copper (II) sulphate (pentahydrate). The flask containing the mixture was heated on a Bunsen burner at an angle of $60^{\circ}$ until the solution was completely 
digested and the color changed from blackish color to bluish green. The solution was allowed to solidify for a period of 24 hours which changed the solution to white color. The solidified sample was dissolved with $200 \mathrm{ml}$ of distilled water and $40 \%$ sodium hydroxide was added to it. The dissolved mixture was transferred into a $500 \mathrm{ml}$ flat bottom flask and two to four pieces of zinc metal were introduced. The flask was connected to the distillation column. In the set-up, $100 \mathrm{ml}$ of $4 \%$ boric acid was prepared in a conical flask and two drops of methyl red indicator was added into it of which a light pink color was obtained. The distillate was allowed to make contact with the boric acid which acts as an absorber. When the liquid in the absorber reached $200 \mathrm{ml}$ marked on the conical flask, the distillation was stopped by disconnecting the distillation apparatus. The absorber was back titrated with $0.1 \mathrm{~N}$ sulphuric acid. The titration was stopped when the color of the distillate turned back to the initial color of the mixture of boric acid and methyl red indicator i.e. a light pink color.

\subsection{The Nitrogen Content Was Calculated as Follows}

$100 \times$ Titer value $\times 0.0014 /$ weight of the sample used.

Where: $100=$ percentage conversion.

$0.0014=$ the constant. This means that $0.0014 \mathrm{~g}$ of Nitrogen will be liberated by $1 \mathrm{ml}$ of $0.1 \mathrm{~N}$ sulphuric acid.

\subsection{Phosphorus Content of the Biofertilizer}

The soil sample was digested with concentrated $\mathrm{H}_{2} \mathrm{SO}_{4}$ and $\mathrm{HNO}_{3}$ in the presence of $\mathrm{CuSO}_{4}$ and $\mathrm{K}_{2} \mathrm{SO}_{4}$. After digestion, the solution was neutralized with $\mathrm{NaOH}$ using phenolphthalein indicator. The solution was treated with ammonium molybdate and stannous chloride solution and was left to stand for $5 \mathrm{mi}-$ nutes. A blue color was obtained and its absorbance was measured with a spectrophotometer at $690 \mathrm{~nm}$.

The phosphorus content was calculated as follows:

Absorbance $\times$ Volume of diluting flask $\times 100 / 1000 \times$ Volume of sample used.

\subsection{Potassium Content of the Biofertilizer}

The soil sample was leached with ammonium acetate solution and the potassium content was estimated by flame photometry.

The potassium content was calculated as follows:

Absorbance $\times$ Volume of diluting flask $\times 100 / 1000 \times$ Volume of sample used.

\section{Application of the Fertilizers}

The Nitrogen:Phosphorus:Potassium (NPK) ratio of the chemical fertilizer used was $\mathrm{N}: 15, \mathrm{P}: 15, \mathrm{~K}: 15$, while the NPK composition of the biofertilizer was $\mathrm{N}: 2.5$, $\mathrm{P}: 3.5, \mathrm{~K}: 2.5$. The planting beds $\left(4 \mathrm{~m}^{2}\right.$ in size) were prepared in triplicates for 
control, chemical fertilizer and biofertilizer respectively. Eight hundred grams (800 gm) of chemical fertilizer was applied on each of the three beds 2 weeks after the corns were cultivated. Ten $(10 \mathrm{ml})$ of the concentrated biofertilizer solution was diluted in $1000 \mathrm{ml}$ ( 1 litter) of distilled water before every application on the crop, which was applied to the corn plants daily, starting from the first day of their germination. Application was carried out at dawn to prevent the destruction of the resident microorganisms in the biofertilizer by the excess heat (sun rays) if applied during the day.

\section{Results}

Biofertilizer consistently and significantly increased the height of corn (Zea mays) compared to other treatments. At six weeks of planting, the height of corn treated with biofertilizer was observed to significantly $(P<0.05)$ increase to $(193$ $\mathrm{cm}$ ) compared to NPK and the control. Also at 8 weeks after planting the height of the corn was observed to significantly $(P<0.05)$ increase to $(225$ $\mathrm{cm}$ ) compared to other treatments (Table 3), with simultaneous higher increase in weight of yeild of plants treated with biofertilizer as against others (Table 6). As indicated in Table 4, the highest value of standard deviation of the biofertilizer showed the improved effect of this treatment on the growth performance of the plants over the other treatments.

Comparative analysis of the chemical compositions of the soil, synthetic/chemical fertilizer and the biofertilizer showed that the chemical fertilizer has equal ratio of nitrogen:phosphorus:potassium of 15:15:15, much higher than the ratio of the chemical composition of biological fertilizer of 2.46:3.49:2.5 and that of the soil-0.6:4.2:2.5 (Table 1). Comparing the above NPK values of the different fertilizers, it could be noticed that these values did not directly translate to the crop performance as shown in Table 4. In other words, it could not be said that the higher the NPK value in any given fertilizer the better the performance of the crop. Other factors have a role to play. Phosphate $(\mathrm{P})$, as one of the most important elements for plant growth, is more abundant in chemical fertilizer than in biofertilizer (Table 1), but its availability is limited to plants [6] [11]. Phosphorus in agricultural soils is mostly present in form of insoluble phosphate and therefore unavailable for plant's utilization (Tables 1-5).

The presence of microbes and other trace elements in the biofertilizer might have contributed to the improved performance of the corn plants treated with biofertilizer as against the performance of the crops treated chemical fertilizer and the control without microbial inoculum. [20] reported the complexity of the interactions of soil organisms and the target plants. A number of bacterial genera have been identified and used as Plant Growth-Promoting Biofertilizer (PGPB) and include Bacillus spp., Pseudomonas spp., and Azotobacter spp. Plant Growth Promoting Biofertilizer or microbial fertilizer has been defined as substance composed of living microorganisms and mixture of biodegradable substances applied to soil, seed or plant surfaces, which colonizes the interior 
Table 1. Chemical composition of the experimental soil (control), chemical fertilizer and biofertilizer.

\begin{tabular}{cccc}
\hline CHEMICAL PARAMETER & NITROGEN & PHOSPHORUS & POTASSUIM \\
\hline SOIL & 0.63 & 4.225 & 2.505 \\
CHEMICAL FERTILIZER & 15 & 15 & 15 \\
BIOFERTILIZER & 2.47 & 3.49 & 2.505 \\
\hline
\end{tabular}

Table 2. Mode of treatments (triplicates): control, chemical fertilizer and biofertilizer.

\begin{tabular}{ccccc}
\hline TREATMENT & BEDS (NO) & CONTROL & $\begin{array}{r}\text { CHEMICAL } \\
\text { FERTILIZER }\end{array}$ & BIOFERTILIZER \\
\hline CONTROL (No treatment) & 1 & - & - & - \\
& 2 & - & - & - \\
$\begin{array}{c}\text { CHEMICAL FERTILIZER } \\
\text { (NPK) }\end{array}$ & 3 & - & - & - \\
& 4 & - & + & - \\
BIOFERTILIZER & 5 & - & + & - \\
& 6 & - & - & + \\
& 7 & - & - & + \\
\hline
\end{tabular}

Beds numbered from 1 - 3 were not treated with any type of fertilizer (Control), beds numbered from 4 - 6 were treated with chemical fertilizer (NPK) and beds numbered from 7 - 10 were treated with biofertilizer.

Table 3. The effect of application of chemical fertilizer and biofertilizer on corn plant growth (measured in height $-\mathrm{cm}$ ).

\begin{tabular}{|c|c|c|c|c|c|c|c|c|c|}
\hline TREATMENT & $\begin{array}{l}\text { NO OF } \\
\text { BEDS }\end{array}$ & $\begin{array}{l}1^{\mathrm{ST}} \\
\mathrm{WK}\end{array}$ & $\begin{array}{l}2^{\mathrm{ND}} \\
\mathrm{WK}\end{array}$ & $\begin{array}{l}3^{\mathrm{RD}} \\
\mathrm{WK}\end{array}$ & $\begin{array}{l}4^{\mathrm{TH}} \\
\mathrm{WK}\end{array}$ & $\begin{array}{l}5^{\mathrm{TH}} \\
\mathrm{WK}\end{array}$ & $\begin{array}{c}6^{\mathrm{TH}} \\
\mathrm{K}\end{array}$ & $\begin{array}{l}7^{\mathrm{TH}} \\
\mathrm{WK}\end{array}$ & $\begin{array}{l}8^{\mathrm{TH}} \\
\mathrm{WK}\end{array}$ \\
\hline \multirow[t]{3}{*}{ CONTROL } & 1 & 6 & 14 & 21 & 40 & 64 & 94 & 140 & 173 \\
\hline & 2 & 5 & 12 & 24 & 41 & 63 & 86 & 137 & 179 \\
\hline & 3 & 5 & 14 & 24 & 52 & 69 & 97 & 130 & 162 \\
\hline \multirow[t]{3}{*}{$\begin{array}{l}\text { CHEMICAL } \\
\text { FER'TILIZER }\end{array}$} & 4 & 5 & 16 & 29 & 53 & 81 & 100 & 148 & 186 \\
\hline & 5 & 6 & 17 & 29 & 53 & 84 & 108 & 155 & 173 \\
\hline & 6 & 6 & 12 & 29 & 50 & 75 & 113 & 141 & 204 \\
\hline \multirow[t]{3}{*}{ BIOFERTILIZER } & 7 & 6 & 17 & 26 & 56 & 82 & 166 & 211 & 225 \\
\hline & 8 & 6 & 17 & 36 & 61 & 98 & 153 & 193 & 208 \\
\hline & 9 & 7 & 17 & 39 & 71 & 104 & 193 & 176 & 193 \\
\hline
\end{tabular}

Plant height was measured from the base of the plant to the tip of the plant.

part of the plant, via rhizosphere or intercellular spaces, that enhanced the growth and yields of the host plant by increasing availability of primary nutrients, such as nitrogen, phosphorus and potassium. They have been tested and reported as effective microbial inoculants used to improve soil and plant fertility 
Table 4. Mean heights of corn plants treated with chemical fertilizer and biofertilizer (cm).

\begin{tabular}{|c|c|c|c|c|c|c|c|c|c|}
\hline TREATMENT & $\begin{array}{l}1^{\mathrm{ST}} \\
\mathrm{WK}\end{array}$ & $\begin{array}{l}2^{\mathrm{ND}} \\
\mathrm{WK}\end{array}$ & $\begin{array}{l}3^{\mathrm{RD}} \\
\mathrm{WK}\end{array}$ & $\begin{array}{l}4^{\mathrm{TH}} \\
\mathrm{WK}\end{array}$ & $\begin{array}{l}5^{\mathrm{TH}} \\
\mathrm{WK}\end{array}$ & $\begin{array}{l}6^{\mathrm{TH}} \\
\mathrm{WK}\end{array}$ & $\begin{array}{l}7^{\mathrm{TH}} \\
\mathrm{WK}\end{array}$ & $\begin{array}{l}8^{\mathrm{TH}} \\
\mathrm{WK}\end{array}$ & SD \\
\hline CONTROL & 5.33 & 13.33 & 23.00 & 44.33 & 65.33 & 92.33 & 135.33 & 171.33 & \pm 7.04 \\
\hline $\begin{array}{l}\text { CHEMICAL } \\
\text { FERTILIZER }\end{array}$ & 5.33 & 15.00 & 29.00 & 52.00 & 80.00 & 107.00 & 148.00 & 187.00 & \pm 12.71 \\
\hline BIOFERTILIZER & 6.33 & 17.00 & 33.67 & 62.67 & 94.67 & 170.67 & 193.33 & 208.67 & \pm 13.07 \\
\hline
\end{tabular}

Table 5. Mean number of corn cobs at harvest per treatment.

\begin{tabular}{ccc}
\hline CONTROL & CHEMICAL FERTILIZER (NPK) & BIOFERTILIZER \\
\hline 12 & 18 & 29 \\
\hline
\end{tabular}

Table 6. Weight of corn per treatment (gm).

\begin{tabular}{ccc}
\hline TREATMENT & $\begin{array}{c}\text { NO OF WHOLE CORNS } \\
\text { WEIGHED }\end{array}$ & WEIGHT OF CORN (gm) \\
\hline CONTROL & 8 & 1840 \\
CHEMICAL FERTILIZER (NPK) & 8 & 1960 \\
BIOFERTILIZER & 8 & 2224 \\
\hline
\end{tabular}

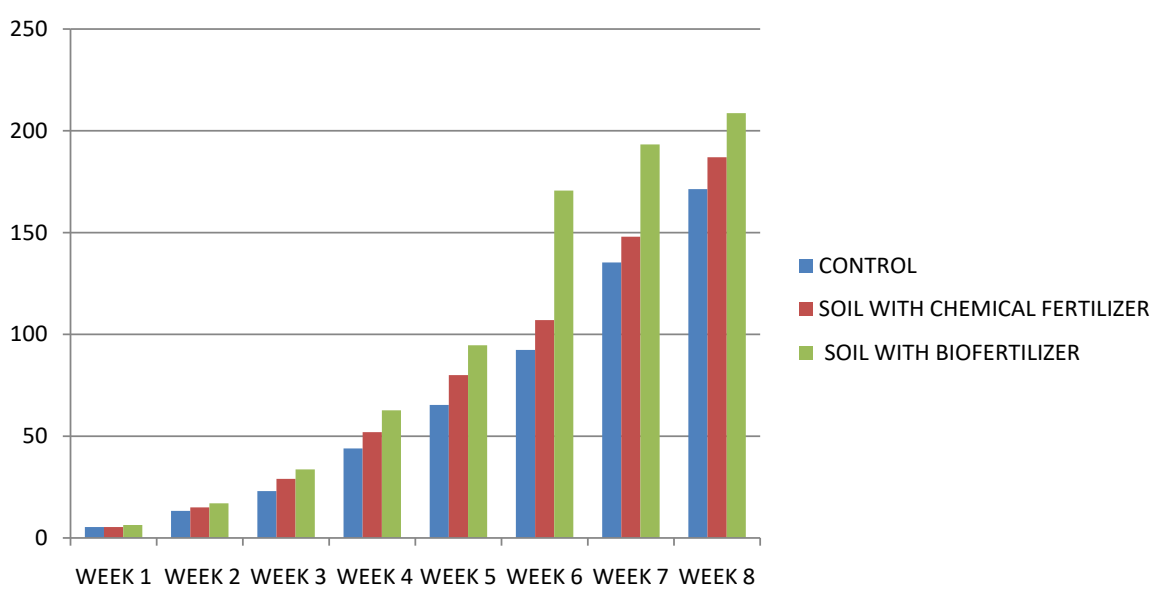

Figure 1. Graphic representation of mean value of growth of corn (Zea mays) planted with the two fertilizers and the control.

[21]-[25] as observed in this work. Nitrogen, Phosphorus, Potassium (NPK) and other trace elements contained in fertilizers had been wrongly described as plant food; however, NPK are vital elements required for cell division and enzyme processes that allow photosynthesis and plant growth. Figures 3-5 above represent corn plants not treated with any fertilizer (control), those treated with chemical fertilizer and those treated with biofertilizer respectively; it could be noticed that while Figure 4 and Figure 5 demonstrated evidence of increased growth against the control plant (Figure 5), apart from increased growth also demonstrated protection against insect/pest attack as shown by the healthier leaves/blades of the plants (Figures 1-5). 


\section{Wt. of Corn(gm)}

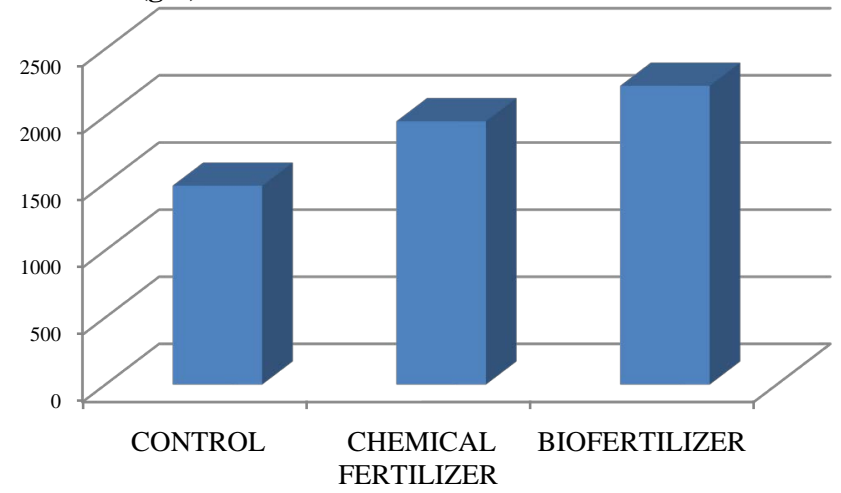

Wt. of Corn(gm)

Figure 2. Mean weight of corn per treatment (gm).

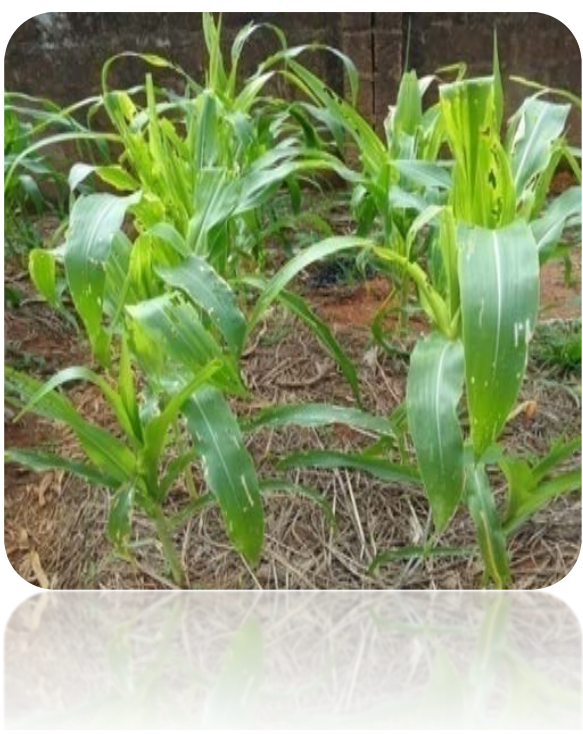

Figure 3. Corn plant (Control).

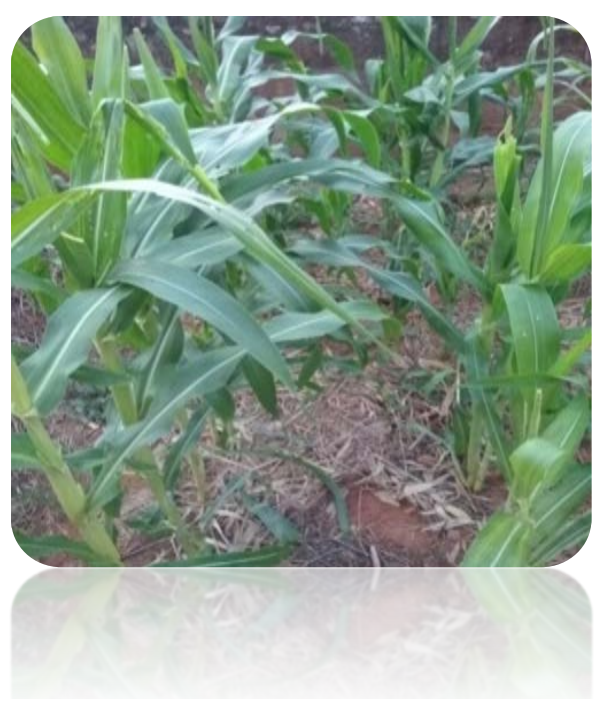

Figure 4. Corn plant treated with chemical fertilizer. 


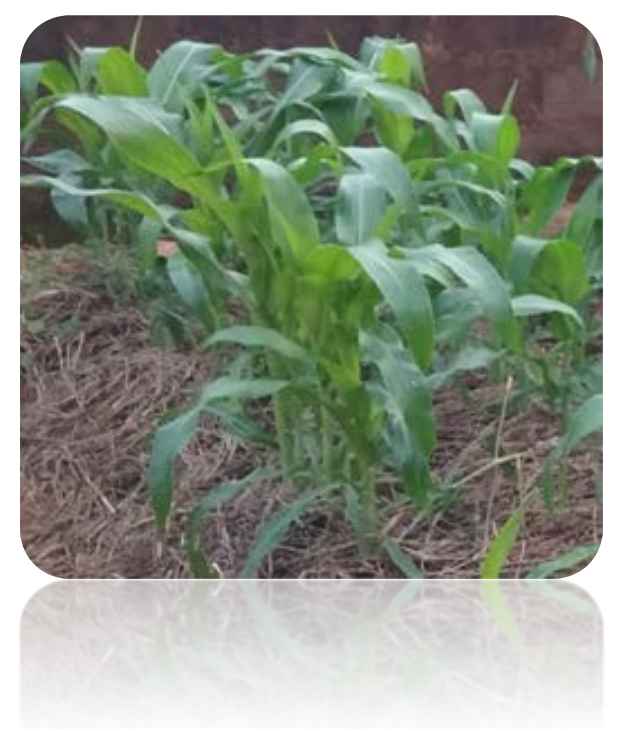

Figure 5. Corn plant treated with biofertilizer.

\section{Conclusion}

Based on the findings and the observations made, it was concluded that the biofertilizer has a higher crop performance efficiency than the chemical fertilizer. The Plant Growth Promoting Bacteria isolated and used as biofertilizer in this research work also demonstrated the ability to protect the corn plants from pathogen/insect attack and therefore can serve as both biofertilizer and biopesticide or biocontrol agent.

\section{Acknowledgements}

The authors are thankful to the Vice Chancellor of Godfrey Okoye University, Thinker's Corner, Enugu, for the supply of the reagents and to the Director and staff of Masdevan Integrated Farming System (Songhai Model), Urum, Awka, Anambra State, Nigeria for their material and infrastructural provision.

\section{Conflicts of Interest}

The authors declare no conflicts of interest regarding the publication of this paper.

\section{References}

[1] Leo, H., Robert, S. and Lawrence, P.W. (2002) How Sustainable Agriculture Can Address the Environmental and Human Health Harms of Industrial Agriculture. Environmental Health Perspectives, 110, 5. https://doi.org/10.1289/ehp.02110445

[2] Serpil, S. (2012) An Agricultural Pollutant: Chemical Fertilizer. International Journal of Environmental Science and Development, 3, 287-292. https://doi.org/10.1016/j.apcbee.2012.03.047

[3] Chandini, R.K., Kumar, R. and Om, P. (2019) The Impact of Chemical Fertilizers on our Environment and Ecosystem. In: Research Trends in Environmental Sciences, 2nd Edition, 71-86. https://www.researchgate.net/publication/331132826 
[4] Schindler, D.W., Hecky, R.E., Findlay, D.L., Stainton, M.P., Parker, B.R., Paterson, M.J., Beaty, K.G., Lyng, M. and Kasian, S.E.M. (2008) Eutrophication of Lakes Cannot Be Controlled by Reducing Nitrogen Input: Results of a 37-Year Whole-Ecosystem Experiment. Proceedings of the National Academy of Sciences of the United States of America, 105, 11254-11258. https://doi.org/10.1073/pnas.0805108105

[5] Khan, A.A., Jilani, G., Akhtar, M.S., Naqvi, S.M.S. and Rasheed, M. (2009) Phosphorus Solubilizing Bacteria: Occurrence, Mechanisms and Their Role in Crop Production. Journal of Agricultural and Biological Science, 1, 48-58.

[6] Abdel Ghany, T.M., Alawlaqi, M.M. and Al Abboud, M.A. (2013) Role of Biofertilizers in Agriculture: A Brief Review. Mycopath, 11, 95-101.

[7] Wagner, S.C. (2011) Biological Nitrogen Fixation. Nature Education Knowledge, 3, 15.

[8] Chandra, D., Srivastava, R. and Sharma, A.K. (2016) Environment Friendly Phosphorus Biofertilizer as an Alternative to Chemical Fertilizers. In: Pati, B.R. and Mandai, S.M., Eds., Recent Trends in Biofertilizers, I.K. International Publisher, New Delhi, 43-71.

https://www.researchgate.net/publication/291345421Environment_friendly_Phosph orus_Biofertilizer_as_an_Alternative_to_Chemical_Fertilizers

[9] Hao, X., Cho, C.M., Racz, G.J. and Chang, C. (2002) Chemical Retardation of Phosphate Diffusion in an Acid Soil as Affected by Liming. Nutrient Cycling in Agroecosystems, 64, 213-224. https://doi.org/10.1023/A:1021470824083

[10] Gowami, S.P., Maurya, B.R., Dubey, A.N., et al. (2019) Role of Phosphorus Solubilizing Microorganisms and Dissolution of Insoluble Phosphorus in Soil. International Journal of Chemical Studies, 7, 3905-3913.

[11] Alam, S., Khalil, S., Ayub, N. and Rashid, M. (2002) In Vitro Solubilization of Inorganic Phosphate by Phosphate Solubilizing Microorganism (PSM) from Maize Rhizosphere. International Journal of Agriculture and Biology, 4, 454-458. https://www.researchgate.net/publication/233815274

[12] Whitelaw, M.A. (2013) Growth Promotion of Plants Inoculated with PhosphateSolubilizing Fungi. Advances in Agronomy, 69, 99-151. https://doi.org/10.1016/S0065-2113(08)60948-7

[13] Oladejo, O.S. and Fasan, A.B. (2015) Production of Bio Fertilizer from Rice Waste, Cow Dung and Timber Sawdust. International Journal of Chemical, Environmental \& Biological Sciences, 3, 96-102.

[14] Vacheron, J., Guilhem, D., Bouffaud, M., Marie-Lara, B., Touraine, B., Moënne-Loccoz, Y., Muller, D., Legendre, L., Wisniewski-Dyé, F. and Prigent-Combaret, C. (2013) Plant Growth-Promoting Rhizobacteria and Root System Functioning. Frontiers in Plant Science, 4, 356. https://doi.org/10.3389/fpls.2013.00356

[15] Singh, P.P., Kujur, A., Yadav, A., Kumar, A., Singh, S.K. and Prakash, B. (2019) Mechanisms of Plant-Microbe Interactions and Its Significance for Sustainable Agriculture. In: PGPR Amelioration in Sustainable Agriculture. Food Security and Environmental Management, Woodhead Publishing, Sawston, 17-39. https://doi.org/10.1016/B978-0-12-815879-1.00002-1

[16] Ritika, B. and Utpal, D. (2014) Bio Fertilizer a Way towards Organic Agriculture. African Journal of Microbiology Research, 8, 2332-2342.

http://www.academicjournals.org/AJMR https://doi.org/10.5897/AJMR2013.6374

[17] Naveed, M., Mehboob, I., Shaker, M.A., Hussain, M.B. and Farooq, M. (2014) Biofertilizers in Pakistan: Initiatives and Limitations. International Journal of Agricul- 
ture \& Biology, 17, 411-420. https://doi.org/10.17957/IJAB/17.3.14.672

[18] Carvajal-Muñoz, J.S. and Carmona-Garcia, C.E. (2012) Benefits and Limitations of Biofertilization in Agricultural Practice. Research Group on Urban and Hazardous Waste (GIRPSU) Integrated Group on Civil Engineering Research (GIIC) Research Group on Soil, Environment and Society University of Magdalena. Santa Marta, Magdalena, Colombia. Carrera 32 No. 22-08.

[19] Pikovskaya, R.I. (1948) Mobilization of Phosphorus in Soil in Connection with Vital Activity of Some Microbial Species. Microbiology, 17, 362-370.

[20] Ingam, E. (2015) USDA Natural Resources Conservation Services: Soil Food Web. http://www.nrcs.usda.gov/wps/portal/nrcs/detailfull/soils/health/biology/?cid=nrcs1 42p2_053868

[21] Kloepper, J.W., Choong-Min, R. and Shouan, Z. (2004) Induced Systemic Resistance and Promotion of Plant Growth by Bacillus spp. The American Phytopathological Society, 94, 1259. https://doi.org/10.1094/PHYTO.2004.94.11.1259 https://apsjournals.apsnet.org/doi/abs/10.1094/PHYTO.2004.94.11.1259

[22] Saharan, B. and Nehra, V. (2011) Plant Growth Promoting Rhizobacteria: A Critical Review. Life Sciences and Medicine Research, 2011, LSMR-21. http://astonjournals.com/lsmr

[23] Kumar, A., Verma, H., Singh, V.K., Singh, P.P., Singh, S.K., Ansari, W.A., Yadav, A., Singh, P.K. and Pandey, K.D. (2017) Role of Pseudomonas sp. in Sustainable Agriculture and Disease Management. Springer, Berlin, 195-215.

https://www.researchgate.net/publication/319937474 https://doi.org/10.1007/978-981-10-5343-6_7

[24] Singh, M., Singh, D., Gupta, A., Panday, D.K., Singh, P.K. and Kumar, A. (2017) Plant Growth Promoting Rhizobacteria: Application in Biofertilizers and Biocontrol of Phytopathogens. In: PGPR Amelioration in Sustainable Agriculture. Food Security and Environmental Management, Elsevier, Amsterdam, 46-66. https://doi.org/10.1016/B978-0-12-815879-1.00003-3

[25] Gamez, R., Cardinale, M., Montes, M., Ramirez, S. and Rodriguez, S. (2019) Screening, Plant Growth Promotion and Root Colonization Pattern of Two Rhizobacteria (Pseudomonas fluorescens Ps006 and Bacillus amyloliquefaciens Bs006) on Banana cv. Williams (Musa ac uminate Colla). Microbiological Research, 220, 12-20. https://doi.org/10.1016/j.micres.2018.11.006 